\title{
Accidental finger ischaemia induced by epinephrine autoinjector
}

\author{
Miguel F Carrascosa, ${ }^{1}$ Adelia Gallastegui-Menéndez, ${ }^{2}$ Carlos Teja-Santamaría, ${ }^{2}$ \\ José-Ramón Salcines Caviedes ${ }^{3}$
}

'Department of Internal Medicine, Hospital of Laredo, Laredo, Cantabria, Spain

${ }^{2}$ Department of Emergency, Hospital of Laredo, Laredo, Cantabria, Spain ${ }^{3}$ Department of Internal Medicine, Section of Digestive Diseases, Hospital of Laredo, Laredo, Cantabria, Spain

Correspondence to Dr Miguel F Carrascosa, miguel.carrascosa@scsalud.es
To cite: Carrascosa MF, Gallastegui-Menéndez $\mathrm{A}$, Teja-Santamaría C, et al. BMJ Case Rep Published online: [please include Day Month Year] doi:10.1136/ bcr-2013-200783

\section{DESCRIPTION}

Epinephrine is the treatment of choice for anaphylactic reactions, and it has to be administered immediately in such a situation. However, unintentional digital injection with this drug is an increasing event. ${ }^{1}$ We report a case of acute finger ischaemia after accidental administration of epinephrine while using an autoinjector device.

A 16-year-old teenager arrived at the emergency department with intense pain, tingling, coldness and blanching of her right thumb (figure 1A). Some $30 \mathrm{~min}$ before, she had inadvertently injected $300 \mu \mathrm{g}$ of epinephrine into the volar pad of her finger while trying to self-treat an allergic reaction. Epinephrine had been prescribed by an allergist because the patient had a history of recurrent anaphylaxis of probable alimentary origin. Examination of the injured digit revealed a puncture wound on the pulp, delayed capillary refill and decreased sensation as well as active and passive range of motion; systemic effects from epinephrine were absent. The attending clinician verified the complete injection of the content of the syringe. As phentolamine was not available in our hospital, immersion in warm water and local injection of salbutamol were initially attempted to reverse vasoconstriction but it turned out unsuccessful. In view of the unremitting digital ischaemia, an anaesthetist and vascular and general surgeons were contacted. Treatment with intravenous alprostadil, a prostaglandin E1 analogue ( $40 \mu \mathrm{g}$ twice a day for 3 days) and subcutaneous enoxaparin $(50 \mathrm{mg}$ every $12 \mathrm{~h}$ for 3 days) was proposed, and it was started $3 \mathrm{~h}$ after admission in addition to prednisone and an antihistaminic drug. Symptoms and signs abated progressively, and she was discharged by day 3 with light pain and impaired active range of motion of her finger as the sole symptom. At a follow-up visit 9 days after discharge, the patient was symptoms free and her right thumb showed a normal appearance (figure 1B).

Errors in handling epinephrine autoinjectors in the first aid treatment of anaphylaxis can lead to unintentional injection, usually in a finger. Although consequences may be serious, whether local (exceptionally leading to finger amputation) or systemic, ${ }^{2}{ }^{3}$ these accidents generally have a favourable outcome within 2-24 h after injection, with or without treatment. ${ }^{2}{ }^{3}$ In fact, there have been instances where patients with accidental finger ischaemia caused by epinephrine have recovered without much medical intervention. ${ }^{1}{ }^{4}$ Hence a wider study with controls seems to be advisable to see if the difference in result is statistically significant. Topical phentolamine, a short-acting $\alpha$-blocker, has been the most commonly used procedure to counter the effects of epinephrine, ${ }^{1}$ but therapeutic approaches to these injuries have not been evaluated in randomised controlled trials yet. Although alprostadil and enoxaparin association could be a therapeutic option for those patients with ongoing finger ischaemia and no possibility to receive phentolamine, there has to be a wider, ethically and methodologically approved clinical trial (ie, preclinical assessment followed by various stages of clinical study) before the use of above-mentioned drugs can be recommended for wider use.

As the utilisation of epinephrine autoinjectors is rising, efforts to prevent associated handling mistakes should be continuously advocated. In practice, it sounds like the most appropriate way to prevent such misuse is to supply precise and repeated training to healthcare professionals, patients and their caregivers.
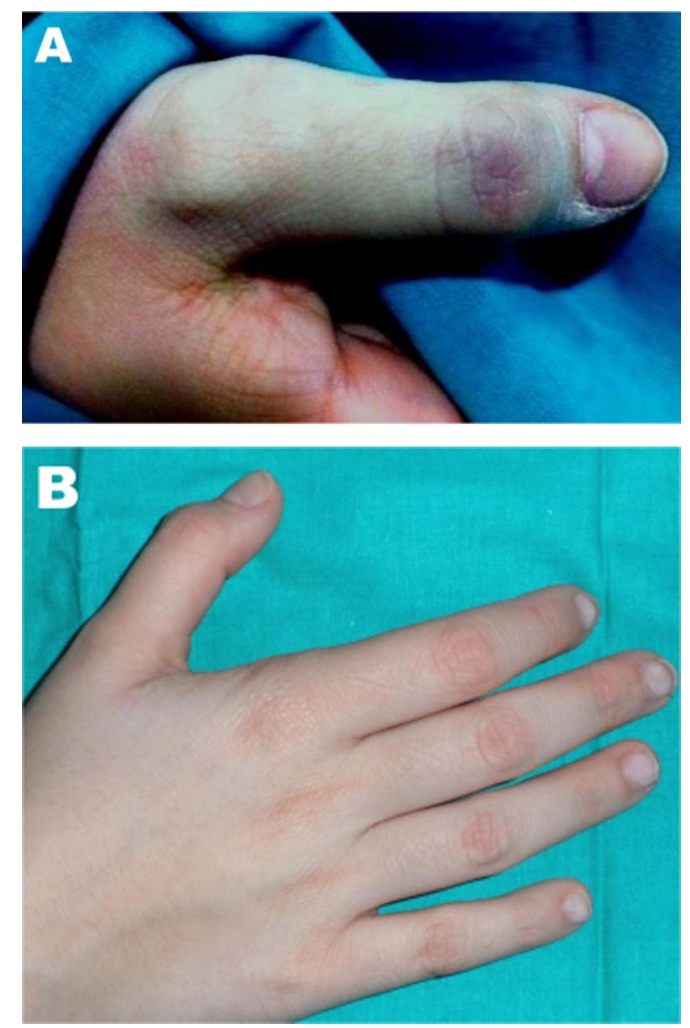

Figure 1 Appearance of the right thumb on admission (A) and follow-up aspect of the right hand 9 days after discharge (B). 


\section{Learning points}

- Errors in handling epinephrine autoinjectors in the treatment of anaphylaxis can lead to unintentional injection, usually in a finger.

- Although consequences may be serious, whether local or systemic, these accidents usually have a favourable outcome, with or without treatment.

- Alprostadil and enoxaparin association could be a suitable therapeutic election for those patients with ongoing digital ischaemia and no possibility to receive local injection of phentolamine.

Contributors MFC was involved in substantial contribution to study conception and design, acquisition of data, analysis and interpretation of data, drafting of the manuscript, critical revision of the manuscript for important intellectual content, administrative, technical or material support, study supervision, final approval of the version to be published. AGM was involved in substantial contribution to study conception and design, acquisition of data, analysis and interpretation of data, critical revision of the manuscript for important intellectual content, administrative, technical or material support, study supervision, final approval of the version to be published. CTS was involved in substantial contribution to study conception and design, acquisition of data, analysis and interpretation of data, critical revision of the manuscript for important intellectual content, final approval of the version to be published. J-RSC was involved in substantial contribution to study conception and design, analysis and interpretation of data, critical revision of the manuscript for important intellectual content, final approval of the version to be published.

Competing interests None.

Patient consent Obtained

Provenance and peer review Not commissioned; externally peer reviewed.

\section{REFERENCES}

1 Fitzcharles-Bowe C, Denkler K, Lalonde D. Finger injection with high-dose $(1: 1,000)$ epinephrine: does it cause finger necrosis and should it be treated? Hand 2007;2:5-11.

2 Accidental injection with adrenaline autoinjectors. Prescrire Int 2012;21:236-9.

3 Simons FER, Lieberman PL, Read EJ, et al. Hazards of unintentional injection of epinephrine from autoinjectors: a systematic review. Ann Allergy Asthma Immunol 2009;102:282-7.

4 Morin RJ, Datiashvili RO. High-dose epinephrine injection into the thumb. Interesting Case Series. http://www.eplasty.com/images/PDF/intresting_case.pdf (accessed 16 Aug 2013).

Copyright 2013 BMJ Publishing Group. All rights reserved. For permission to reuse any of this content visit http://group.bmj.com/group/rights-licensing/permissions.

BMJ Case Report Fellows may re-use this article for personal use and teaching without any further permission.

Become a Fellow of BMJ Case Reports today and you can:

- Submit as many cases as you like

- Enjoy fast sympathetic peer review and rapid publication of accepted articles

- Access all the published articles

- Re-use any of the published material for personal use and teaching without further permission

For information on Institutional Fellowships contact consortiasales@bmjgroup.com

Visit casereports.bmj.com for more articles like this and to become a Fellow 